\section{Physical-Chemical Assessment of Surface Water Pollution in a Micro-Water Basin in the Highlands of Jalisco, Mexico}

\section{Aldo Antonio Castañeda Villanueva*}

Department of Engineering, Comprehensive Water, University of Guadalajara, Jalisco, Mexico

\begin{abstract}
Much of human well-being depends on ecosystems, a body of water can be used in different ways: as a source of drinking water, for agricultural irrigation, including for energy generation, many water sources support food production; in short, life on our planet is sustained through sensitive interrelationships with various natural resources, such as water flows. In the particular case that the river is an ecosystem of great richness and complexity, necessary for the sustainability of population centers, true urban planning must consider the proper conservation of the natural causes of water (rivers and streams, among others), avoiding using these routes as waste and wastewater collectors. The present study monitors three times the main water bodies of the "Jihuite" micro-basin located in the municipality of Tepatitlan in the highlands of Jalisco, Mexico, during one year (2018-2019), for example, in the dam the ammoniacal Nitrogen ( $\mathrm{N}$ ammon), the Oxygen Reduction Potential (ORP) and Specific Conductivity (SC) are increased, decreasing the Concentration of Oxygen Dissolved (COD) to $8.1 \mathrm{mg} / \mathrm{L}$ (at a temperature of $70.2^{\circ} \mathrm{F}$ ), as the volume of water content decreases, as well as the behavior of the physic-chemical quality of water in the river Tepatitlan shows significant decreases since its origin in the confluence of water several streams to the exit of the municipality of Tepatitlan, which is demonstrated by the fact that as the river passes through the urban stain of the city and the municipality of Tepatitlan itself, the $\mathrm{N}$ ammon, the $\mathrm{Cl}-$-, the ORP and the SC increase, corroborating with the corresponding
\end{abstract}

*Corresponding author: Aldo Antonio Castañeda Villanueva, Department of Engineering, Comprehensive Water, University of Guadalajara, Jalisco, Mexico. Tel: +52 3787828033; E-mail: acastaneda@cualtos.udg.mx

Citation: Villanueva AAC (2020) Physical-Chemical Assessment of Surface Water Pollution in a Micro-Water Basin in the Highlands of Jalisco, Mexico. $J$ Environ Sci Curr Res 3: 020

Received: March 17, 2020; Accepted: March 27, 2020; Published: April 03, 2020

Copyright: (c) 2020 Villanueva AAC. This is an open-access article distributed under the terms of the Creative Commons Attribution License, which permits unrestricted use, distribution, and reproduction in any medium, provided the original author and source are credited. decrease in COD to a value of $1.0 \mathrm{mg} / \mathrm{L}$ at the exit of the municipality in the dry season, with a dilution ratio of approximately one in 10.

Keywords: Highlands of Jalisco Mexic; Hydrological micro-basin; Physic-chemical parameters of water; Surface water quality

\section{Introduction}

Much of human well-being depends on ecosystems, a body of water can be used in different ways: as a source of drinking water, for agricultural irrigation, including for energy generation, many water sources support food production; in short, life on our planet is sustained through sensitive interrelationships with various natural resources, such as water flows. In the particular case that the river is an ecosystem of great richness and complexity, necessary for the sustainability of population centres, true urban planning must consider the proper conservation of the natural causes of water (rivers and streams, among others), avoiding using these routes as waste and wastewater collectors. The present study monitors three times the main water bodies of the "Jihuite" micro-basin located in the municipality of Tepatitlan in the highlands of Jalisco, Mexico, during the period of one year (2018-2019), for example, in the dam hydrographic basin is a geographical and hydrological concept that is defined as the area of the earth's surface where rain, snow or thaw water drains and/or transits through a network of currents that flow into a mainstream and by this towards a common point of exit, which can be internal water storage, such as a lake, a lagoon or a dam reservoir, in which case it would be an endorheic basin; When the discharges reach the sea it is called exorheic basin, usually the mainstream is what defines the name of the basin. The main currents in the basins are regularly rivers, that is to say, natural currents subjected to climatic changes and to the characteristics of the basin, the quality of its water varies naturally over time and its course due to the combination of environmental factors, however, human activities alter, sometimes irreversibly, the physical, chemical and biological characteristics of water [1]. Among the main sources of contamination of surface water huts such as rivers and streams, are the discharges of municipal and industrial wastewater, as well as the return flows generated by agricultural activities. In recent years in our country, contamination of surface waters has been one of the problems that have begun to be studied and documented consistently [2], despite the multidimensional conceptual assessment of "quality of water", has generated inconveniences, the handling of data as well as its interpretation are usually a complicated and often difficult work for the general public [3], specifically when seeking to standardize global quality, to the different applications, the situation becomes more complex. The Jihuite micro-basin is located in the municipality of Tepatitlan in the state of Jalisco (Figure 1).

Tepatitlan has a territorial extension of 542.2 square miles, altitude above sea level of 1806, its population in 2015 was 141,322 of which 95,534 people lived at the head municipal (67.6\%), comparatively $3.8 \%$ higher than the population in 2010 , it is estimated that with this rate, by 2020 the population will increase to 153,678 inhabitants [4]. 
Citation: Villanueva AAC (2020) Physical-Chemical Assessment of Surface Water Pollution in a Micro-Water Basin in the Highlands of Jalisco, Mexico. J Environ Sci Curr Res 3: 020.

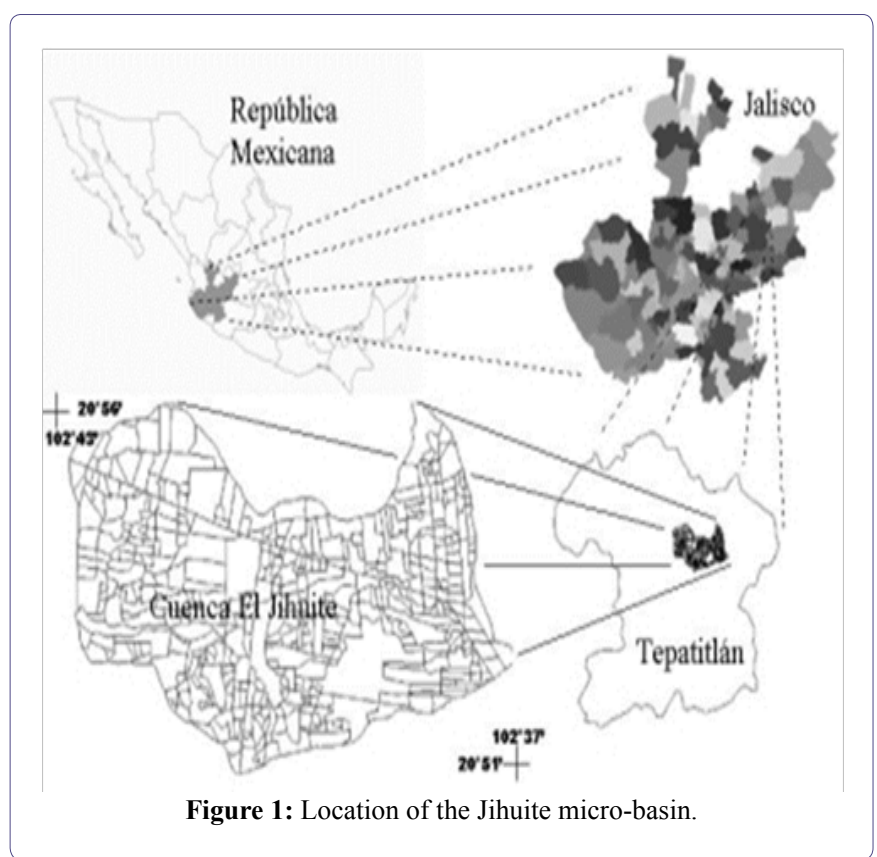

Historical data of weather stations near the municipality indicates that most of the municipality $(71.6 \%)$ has a semi-warm and semi-humid. According to the Jalisco Statistical and Geographic Information System, the annual average temperature recorded in this municipality is $64{ }^{\circ} \mathrm{F}$, while its average maximum and minimum range between $86.4^{\circ} \mathrm{F}$ and $41.7^{\circ} \mathrm{F}$ respectively, being in June when the highest temperatures are recorded and the coldest month of January, the annual average precipitation of the municipality is 34.17 inches, as well as the annual average potential evaporation, is 23.62 inches, presenting the months with the highest index, in March until June (SIEG).

On the other hand, the value of agricultural production in Tepatitlan has shown growth during the period 2012-2016, having registered its highest level in 2016 (81,550 million of US dollars), this value in 2012 represented only $0.9 \%$ of the total State agricultural production and had its maximum participation in 2016 contributing $3.3 \%$ of the state total in that year, in the same way, livestock production has maintained an increasing trend during the same period, being the year 2016 the one that registered the highest value $(634,831$ million of US dollars). In 2012, Tepatitlan's livestock production represented 15.5 $\%$ of the total livestock production in the state, however, in 2013 it stood out for greater participation, reaching $16.9 \%$ of the state's production [4]. In terms of urban solid waste, the municipality generates $1.47 \%$ of the state total, equivalent to 110.26 tons produced per day [5].

The municipality of Tepatitlan according to the National Water Commission [6], is within the administrative hydrological region VIII "Lerma-Santiago-Pacifico", in the hydrological region 12; "Lerma-Santiago", in the hydrological zone "Rio Santiago in the "Río Verde", "Río Santiago"and"Río del Valle"Hydrological Basins, in the"Lerma - Chapala"Hydrological Zone in the"Río Zula"Hydrological Basin.

The main currents in the municipality are the rivers: Tepatitlan, Verde, Calderon and Los Arcos (Figure 2), it also has the streams:
Laborcilla, Milpillas, Juanacasco, San Pablo, Tecolote, Jesus Maria, Peron, Mezcala, Guayabo, La Vieja, Jihuite and El Ocote, as well as the Carretas, Jihuite, La Red, Calderon, La Vieja and El Pantano dams.

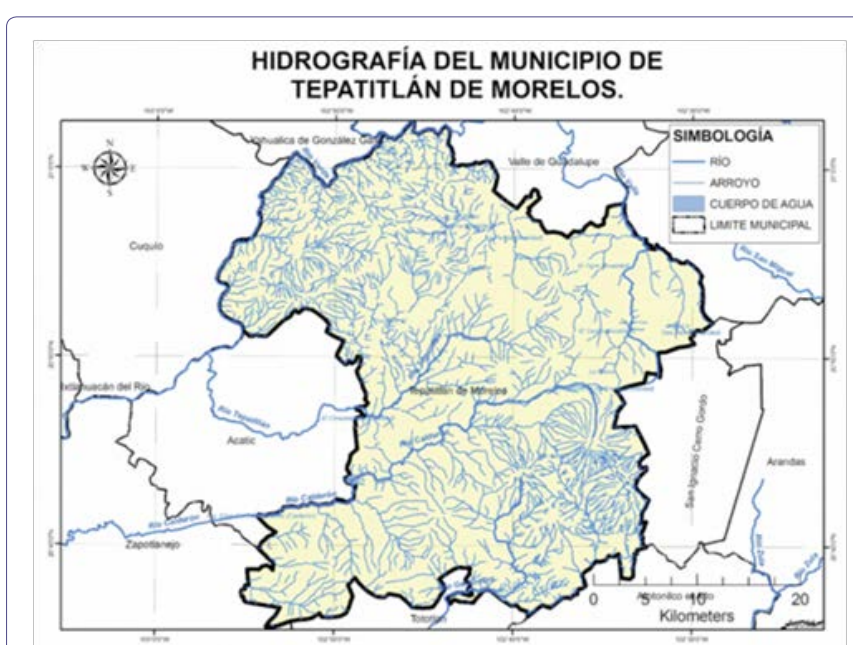

Figure 2: Hydrography of the municipality of Tepatitlan Jalisco.

The Tepatitlanriver (Figure 3) presents a route from northeast to southwest in the municipality of Tepatitlan and from east to north in the municipality of Acatic, originates from the Jihuite stream in which. In 1964, the dam Jihuite was built for a nominal capacity of 176.6 million cubic feet (Figure 4). After 5.5 miles from the Jihuite dam, in the city of Tepatitlán, the Tecolote, Gloria and Durazno streams join the jihuite stream, originating the Tepatitlan river, this river crosses the urban area of the city of Tepatitlán, entering the municipality of Acatic, where it forms a small reservoir, 9 miles later it joins the Verde River, on the limits of the municipalities of Acatic and Cuquio.

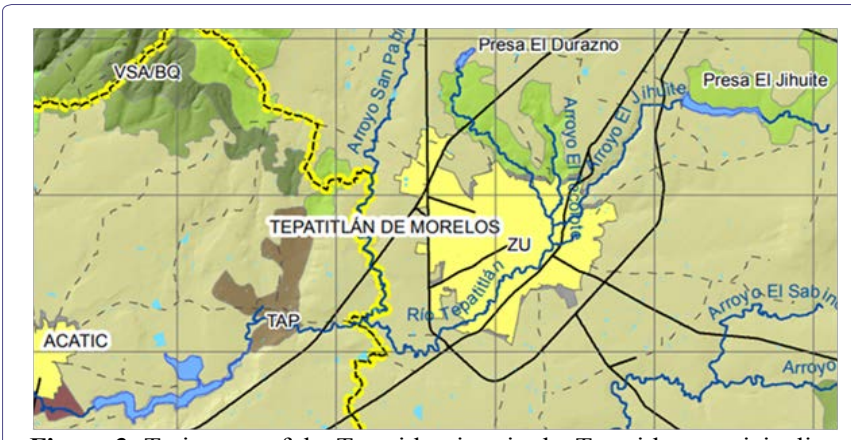

Figure 3: Trajectory of the Tepatitlanriver in the Tepatitlan municipality.

With this study, the parametric water quality was monitored in different parts of the Tepatitlanriver, in its path within the municipality of Tepatitlan Jalisco and the Jihuite dam with three measurements in a chronological period of one year, evaluating its behaviour and possible causes.

\section{Materials and Methods}

The micro-basin of Jihuite is located northeast of the state of Jalisco, geographically it is located between the parallels $20^{\circ} 50^{\prime} 57^{\prime \prime}$ and 
Citation: Villanueva AAC (2020) Physical-Chemical Assessment of Surface Water Pollution in a Micro-Water Basin in the Highlands of Jalisco, Mexico. J Environ Sci Curr Res 3: 020.

$20^{\circ} 55^{\prime} 50^{\prime \prime}$ North and the meridians $102^{\circ} 36^{\prime} 50^{\prime \prime}$ and $102^{\circ} 43^{\prime}$ 'West (Figure 5), with an altitude of 6233 to 7054 feet above sea level, with an approximate area of $14,457.2$ acres, plus 133.36 acres corresponding to the dam reservoir, for a total of $14,590.56$ acres [7].

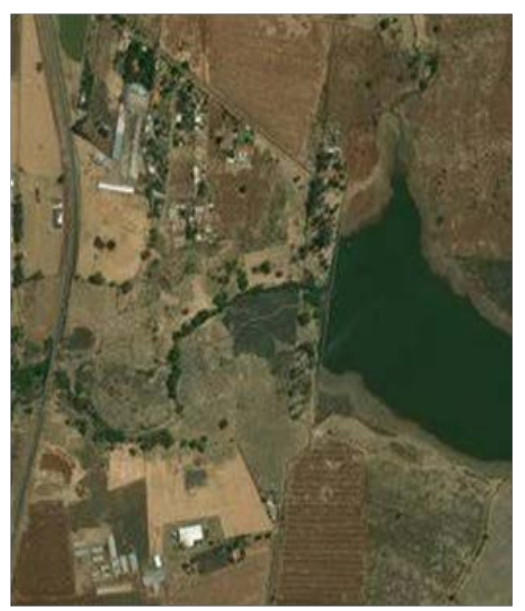

Figure 4: Jihuite dam and stream.

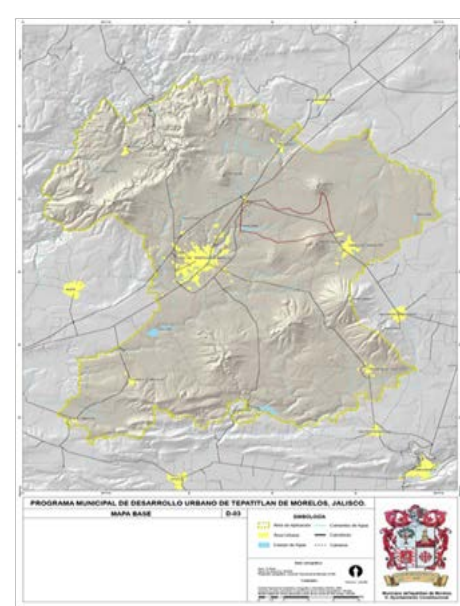

Figure 5: Jihuite's micro-basin in the municipality of Tepatitlan Jalisco (Source: INEGI).

In 2005, the main land uses in Jihuite micro-basin were for livestock activities and agriculture (Figure 6).

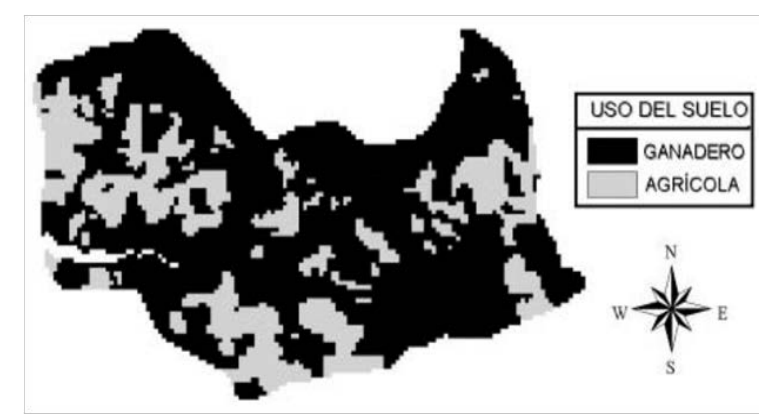

Figure 6: Land use in the micro-basin of Jihuite.
The predominant topography is hills with slopes of 1 to $58 \%$, according to the cartography of the National Institute of Statistics, Geography and Informatics (INEGI), the soil is largely luvisol ferric, of clay texture or clay crumb, with a depth of up to one meter, another type of soil that occurs in the northern part is the eutrophic planosol, of clayey texture with a depth of 15.75 inches or less. The use of the land indicates that about $30 \%$ of the area is dedicated to annual crops, $10 \%$ to temporary meadows, $55 \%$ to a land where cattle graze, with native species and $5 \%$ is used as roads, buildings and other uses. The land ownership regime is a small property, agricultural and industrial activities in the highlands of Jalisco represent an important supply of raw materials and basic foods, both for the region itself and for other parts of the country, however and these activities affect the sustainability of natural resources such as water.

The Tepatitlanriver has its origin practically in the confluences of the streams, Tecolote and Jihuite within the urban spot of the Tepatitlan city (sampling point 3 ), travels around 10.3 miles in the Tepatitlan municipality and 12.2 miles in the Acatic municipality until its mouth in the Verde River. Through geographical information such as the hydrographic features of the municipality of Tepatitlan, as well as field trips, 6 points were established for monitoring and sampling, one in the Jihuite dam and 5 along the Tepatitlanriver from its origin to the exit of the municipality of Tepatitlan, its location is shown in figure 7.

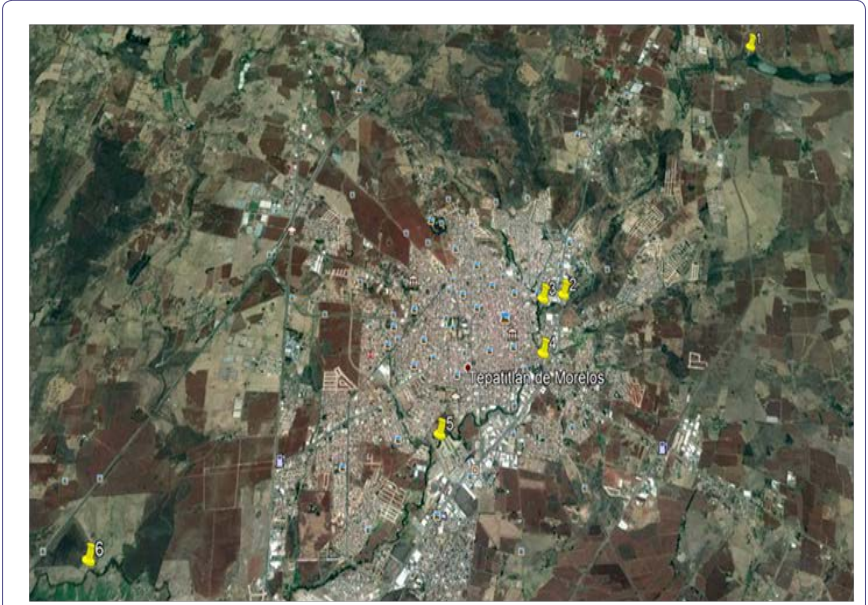

Figure 7: Location of monitoring and sampling points.

For the quantification of the parameters that reflect water quality, a Hydrolab multiparameter probe model DS5X (OTT Hydromet) was used. The quantified parameters and the sensors used in the probe were:

1. Temperature: Through a variable resistance transmitter.

2. Hydrogen Potential $(\mathrm{pH})$ : Using the electrochemical method for the voltage difference between a sensitive glass electrode and a reference electrode.

3. Ammonia or ammonia nitrogen ( $\mathrm{N}$ ammon): It is one of the transitory components in water since it is part of the nitrogen cycle and is influenced by biological activity, it is also the natural product of decomposition of organic compounds nitrogenous, surface waters must not naturally contain ammonia, in general, the presence of free ammonia (ammonium ion) is considered a chemical test of 
Citation: Villanueva AAC (2020) Physical-Chemical Assessment of Surface Water Pollution in a Micro-Water Basin in the Highlands of Jalisco, Mexico. J Environ Sci Curr Res 3: 020.

recent and dangerous contamination, its main origin is; industrial and livestock wastewater (animal excreta, fertilizer) and plant rot, it is maximum permissible value in drinking water is $0.50 \mathrm{mg} / \mathrm{L}$ (NOM-127SSA1-1994).

4. Chlorides (Cl-): They are anions commonly present in freshwater; their maximum permissible concentrations for drinking water are $250 \mathrm{mg} / \mathrm{L}$ (NOM-127SSA1-1994).

5. Concentration of Oxygen Dissolved (COD): It is a measure of the amount of oxygen present in the water and available for breathing, this concentration is controlled by several factors, including the consumption of aerobic organisms such as bacteria and fish, the consumption of plants such as algae, temperature and depth, is a fundamental parameter to classify the level of contamination in surface waters by comparing their values at the same temperature conditions with saturated oxygen saturated water, for example, at $68{ }^{\circ} \mathrm{F}$ and an atmosphere of pressure the oxygen saturation in water is $9.1 \mathrm{mg} / \mathrm{L}$ [8]. It was determined by optical measurement (luminescence technique), by an oxygen-sensitive layer, excited by a blue light source.

6. Specific Conductance (SC): Water can conduct electric current and depends on the amount of solid matter dissolved, it is an indirect measure of the number of ions in solution (mainly nitrate, sulfate, phosphate, sodium, magnesium and calcium), untreated sewage discharges to water bodies usually increase their conductivity, the basic unit for measuring specific conductivity is milli Siemens per centimeter $(\mathrm{mS} / \mathrm{cm})$, the $\mathrm{SC}$ is an important measure of water quality since it indicates the amount of matter dissolved in it; significant changes can be indicators of specific pollution events. It was measured by 4 graphite electrodes in an open cell, salinity is derived from the measurements of these sensors.

7. Oxygen Reduction Potential or Redox potential (ORP): It is a measure of the oxidation state of a system, it measures the tendencies of electrons when flowing to/from a noble metal electrode, it is quantified in Millivolts $(\mathrm{mV})$ and is another indicator of water pollution.

The precision and resolution of the parameters are specified by the manufacturer of the equipment and can be checked in table 1 (DS5X -User Manual).

\begin{tabular}{|c|c|c|c|}
\hline Parameter & Accuracy & Resolution & Range \\
\hline Temperature $\left({ }^{\circ} \mathrm{F}\right)$ & \pm 0.10 & 0.01 & 23 a 122 \\
\hline $\mathrm{pH}$ & \pm 0.2 & 0.01 & $0-14$ \\
\hline $\mathrm{N}$ ammon. $(\mathrm{mg} / \mathrm{L}-\mathrm{N})$ & \pm 2 & 0.001 & $0-100$ \\
\hline $\mathrm{Cl}-(\mathrm{mg} / \mathrm{L})$ & \pm 2 & 0.0001 & 0.5 a 18,000 \\
\hline $\mathrm{COD}(\mathrm{mg} / \mathrm{L})$ & $\begin{array}{c} \pm 0.01 \text { de } 0-8 \\
\pm 0.2>8\end{array}$ & 0.01 & $0-30$ \\
\hline $\mathrm{SC}(\mathrm{mS} / \mathrm{cm})$ & $\pm 1 \%$ of the value read & 0.0001 & O a 100 \\
\hline ORP $(\mathrm{mV})$ & \pm 20 & 1 & -999 a 999 \\
\hline
\end{tabular}

Table 1: Parameters and specifications of the equipment used. Source: DS5X probeuser manual.

The probe is connected to the Surveyor interface that shows the readings instantly of each parameter, with the option of storing the determinations for later downloading them to a computer.
Punctual samples of surface water were taken and the determinations were made in each of the 6 points designated above, during three sampling campaigns, ensuring the 2018 and 2019 season: The first one during March 2018, the second one in January 2019 and the third one in March 2019. The samplings, as well as the field determinations, were carried out respecting the international criteria recommended by the standardized methods [8].

\section{Results}

Practically the Tepatitlan river is born in the Jihuite micro-basin, which has an extension of approximately $15,708.49$ acres, with a length of the main channel of 9,575.6 miles and a $3.55 \%$ average slope of the main channel, this river has several tributaries, mainly of itcrosses the municipalities of Tepatitlán and Acatic, ending at the Verde River at the boundaries of the municipalities of Acatic and Cuquio,

The characterization of the waters of the dam as well as the river was carried out based on the official regulations in force, following international regulations recognized in Mexico.The location of sampling points and their description of the Tepatitlanriver's trajectory is shown in table 2:

\begin{tabular}{|c|c|c|c|}
\hline Sampling Points & Key Identification & Municipality & Description \\
\hline 1 & JD & Tepatitlan & Jihuite dam \\
\hline 2 & TE & Tepatitlan & $\begin{array}{c}\text { At the entrance of } \\
\text { Tepatitlán }\end{array}$ \\
\hline 3 & CTS & Tepatitlan & $\begin{array}{c}\text { Conjunctionwith Teco- } \\
\text { lotestream }\end{array}$ \\
\hline 4 & TC & Tepatitlan & TepatitlanCenter \\
\hline 5 & ET & Tepatitlan & At the exit of Tepatitlan \\
\hline 6 & EAM & $\begin{array}{c}\text { Tepatitlan } \\
\text {-Acatic }\end{array}$ & $\begin{array}{c}\text { At the entrance of the } \\
\text { Acatic municipality }\end{array}$ \\
\hline
\end{tabular}

Table 2: Geographical location of the monitoring points in the Tepatitlanriver.

Source: Own elaboration.

The parametric results of the three monitoring campaigns are shown in table 3.

The average temperature in the monitoring campaigns was $66.2^{\circ} \mathrm{F}$, with a minimum of $63.48^{\circ} \mathrm{F}$ and a maximum of $70.45^{\circ} \mathrm{F}$. The $\mathrm{pH}$ variation did not become very significant; the range of variation was between 7.37 to 6.17 .

The highest concentration of Ammoniacal nitrogen was presented at the exit of the municipality, at monitoring point 6, in March 2019, reaching $4.47 \mathrm{mg} / \mathrm{L}$ (Graph 1).

The concentration of chlorides gradually increased to the maximum values at the exit of the municipality (Graph 2).

The complex of the Oxygen Reduction Potential (ORP), likewise indicates greater critical conditions at the exit, due to the increase of the anionic oxidative states greater at the exit (Graph 3).

The amount of oxygen dissolved drastically diminished, mainly at the exit, which reflects a high organic content in decomposition (Graph 4). 
Citation: Villanueva AAC (2020) Physical-Chemical Assessment of Surface Water Pollution in a Micro-Water Basin in the Highlands of Jalisco, Mexico. J Environ Sci Curr Res 3: 020

\begin{tabular}{|c|c|c|c|c|}
\hline Parameter (units) & Sampling Point & March/18 & January/19 & March/19 \\
\hline \multirow{6}{*}{$\begin{array}{l}\text { Temperature } \\
\left({ }^{\circ} \mathrm{F}\right)\end{array}$} & 1 & 67.64 & 63.48 & 67.48 \\
\hline & 2 & 68.54 & 64.67 & 68.16 \\
\hline & 3 & 69.30 & 65.70 & 68.45 \\
\hline & 4 & 69.70 & 66.00 & 69.42 \\
\hline & 5 & 70.45 & 65.21 & 70.00 \\
\hline & 6 & 69.64 & 65.70 & 70.18 \\
\hline \multirow{6}{*}{$\mathrm{pH}$} & 1 & 7.14 & 7.37 & 7.03 \\
\hline & 2 & 7.02 & 7.12 & 7.00 \\
\hline & 3 & 6.94 & 7.02 & 6.84 \\
\hline & 4 & 6.73 & 6.96 & 6.41 \\
\hline & 5 & 6.87 & 6.83 & 6.36 \\
\hline & 6 & 6.54 & 6.68 & 6.17 \\
\hline \multirow{6}{*}{$\begin{array}{c}\mathrm{N} \text { ammon } \\
(\mathrm{mg} / \mathrm{L})\end{array}$} & 1 & 0.87 & 0.79 & 1.25 \\
\hline & 2 & 1.78 & 1.33 & 2.08 \\
\hline & 3 & 2.01 & 1.46 & 2.67 \\
\hline & 4 & 2.36 & 1.89 & 2.81 \\
\hline & 5 & 2.44 & 1.97 & 2.86 \\
\hline & 6 & 3.57 & 2.47 & 4.47 \\
\hline \multirow{6}{*}{$\underset{(\mathrm{mg} / \mathrm{L})}{\mathrm{Cl}}$} & 1 & 4534 & 3433 & 5650 \\
\hline & 2 & 3672 & 2903 & 4771 \\
\hline & 3 & 4870 & 3555 & 12771 \\
\hline & 4 & 7650 & 6759 & 23572 \\
\hline & 5 & 8761 & 7549 & 33663 \\
\hline & 6 & 34764 & 10997 & 54334 \\
\hline \multirow{6}{*}{$\begin{array}{c}\mathrm{COD} \\
(\mathrm{mg} / \mathrm{L})\end{array}$} & 1 & 8.4 & 8.4 & 8.1 \\
\hline & 2 & 7.1 & 7.4 & 6.2 \\
\hline & 3 & 6.1 & 7.1 & 6.1 \\
\hline & 4 & 5.8 & 6.7 & 5.3 \\
\hline & 5 & 5.7 & 6.6 & 4.6 \\
\hline & 6 & 1.1 & 2.3 & 1.0 \\
\hline \multirow{6}{*}{$\begin{array}{c}\mathrm{SC} \\
(\mathrm{mS} / \mathrm{cm})\end{array}$} & 1 & 111 & 97 & 138 \\
\hline & 2 & 153 & 108 & 149 \\
\hline & 3 & 236 & 147 & 348 \\
\hline & 4 & 564 & 237 & 678 \\
\hline & 5 & 638 & 343 & 769 \\
\hline & 6 & 875 & 545 & 989 \\
\hline \multirow{6}{*}{$\begin{array}{l}\text { ORP } \\
(\mathrm{mV})\end{array}$} & 1 & -131 & -98 & -149 \\
\hline & 2 & -142 & -119 & -168 \\
\hline & 3 & -279 & -158 & -335 \\
\hline & 4 & -311 & -168 & -359 \\
\hline & 5 & -337 & -148 & -373 \\
\hline & 6 & -337 & -229 & -418 \\
\hline
\end{tabular}

Table 3: Results in the three monitoring campaigns.

Source: Own elaboration

In the same way, the increase in the Specific Conductance confirms the persistence of greater quantities of dissipated particles at the exit (Graph 5).

There is a municipal wastewater treatment plant that treats a portion of the wastewater generated by the Tepatitlan population, which has a capacity of 52 Gallons Per Second (GPS), but it has several operational deficiencies, it discharges its treated water in the Tepatitlan river, at the exit of the urban area, between mustard gates 5 and 6 .
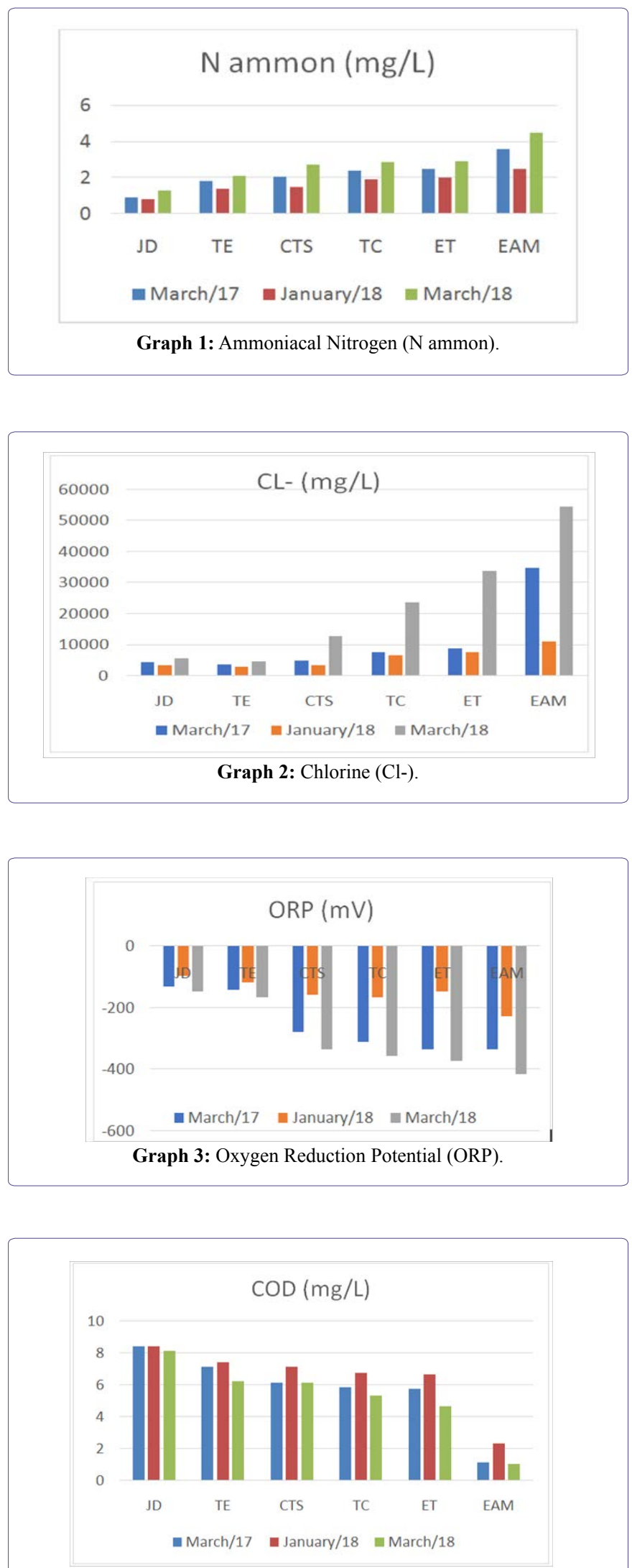

Graph 4: The Concentration of Oxygen Dissolved (COD) 
Citation: Villanueva AAC (2020) Physical-Chemical Assessment of Surface Water Pollution in a Micro-Water Basin in the Highlands of Jalisco, Mexico. J Environ Sci Curr Res 3: 020.

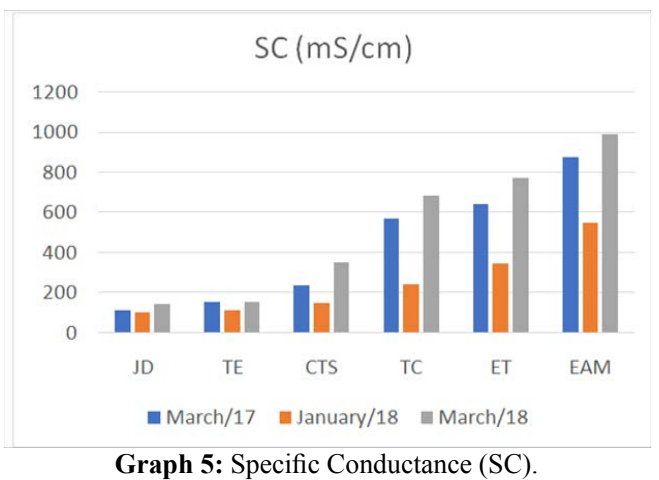

\section{Conclusion}

The main water bodies in the Jihuite micro-basin at Tepatitlan municipality, Jalisco, are the "Jihuite" dam with a storage capacity of 176.6 million cubic feet, built-in 1964 and the Tepatitlan river that was born by joining several streams, 5.3 miles from the Jihuite dam, within Tepatitlan city's urban stain, its trajectory is northeast to southwest with a length of approximately 40 miles, with average flow rates in sampling periods (dry time) of 1,200 GPS.

Considering as a reference, both international and current regulations in our country on the maximum permitted levels of pollutants in water for human and animal consumption, specifically Mexican official standards: NOM-127SSA1-1994 and NOM-003-ECOL-1997, with this study, it is possible to conclude that according to the values obtained from COD at the average temperature of the measurements $\left(66.2^{\circ} \mathrm{F}\right)$, at sampling points 4,5 and 6 corresponding to the center of Tepatitlan, the exit from the urban area and the exit from the municipality, with values below the conditions necessary to maintain the aquatic life at the corresponding temperatures $(9 \mathrm{mg} / \mathrm{L})$, it is also possible to observe significant increases in $\mathrm{N}$ ammon, $\mathrm{ORP}, \mathrm{Cl}$ - and $\mathrm{SC}$, which confirms that as the river waters pass through both the urban stain of Tepatitlan and the municipality itself, its physic-chemical quality drastically diminishes, which is confirmed by the corresponding decrease in COD that at the exit of the municipality and enter the neighboring municipality of Acatic (sampling point 6) to reach values of $1.0 \mathrm{mg} / \mathrm{L}$ in the dry season, with a dilution ratio of approximately 1 in 10 (drying time).

About the water of the "Jihuite" dam (sampling point 1), it is possible to indicate that parameters such as $\mathrm{N}$ ammon, ORP and SC are increased as the volume of water contained therein decreases (March, dry season), as well as the amount of dissolved oxygen (COD) decreases to $8.1 \mathrm{mg} / \mathrm{L}$, the minimum value (at a temperature of 70.2 ${ }^{\circ} \mathbf{F}$ ), indicating the concentration of pollutants such as discharges of organic matter from animal exploration in the micro-basin.

Under these conditions, both river and Jihuite dam waters are not suitable for human and/or animal consumption, possibly also for agricultural use, the above situation is similar to that of other water bodies in the region which receive wastewater discharges without treatment from both urban centers and livestock holdings [2].

In general, the low COD indicates a high level of organic matter, it is also evident that pollutants tend to concentrate on dry seasons (March to May), since in these periods the flow significantly decreases from the river, the presence of ammonia free ( $\mathrm{N}$ ammon) is also considered as a chemical test of recent and dangerous contamination (info.jalisco.gob).

The main sources of non-point contamination in the Jihuite micro-basin (Dam and Tepatitlanriver) are the overapplication of agrochemicals (fertilizers) and stirring in crop fields, the widespread application of pesticides and livestock waste in grasslands, which during rainfall surface to the various water bodies, the change of land use as monocultures such as that of the tequila agave increase every year but, as well as overgrazing and deforestation in general.

Point-in-time pollution in the region can be seen in the limited capacity for domestic wastewater treatment, since in Tepatitlan's care with a population of 95,534 (2015) it generates an approximate volume of 135 GPS of sewage, of which only $40 \%$ (54 GPS) are treated [9]. Besides, practices have been identified to unload wastewater from untreated pig farms and the Tepatitlanriver itself. s mentioned above, the point-in-time contamination of the survey area is largely due to the excessive application of nutrients and fertilizers on agricultural land, as well as the widespread application of pesticides and livestock residues in grasslands, which during rains are shallow to the dam such as the Tepatitlanriver, as well as overgrazing, deforestation and indiscriminate planting of tequila agave, which is aggravating this problem in the region [10].

Proposals to reverse these conditions may include the expansion and optimization of municipal treatment systems, the elimination of clandestine discharges, the promotion of adequate and accessible treatment systems for micro-basin livestock companies, the development of harvesting and maintenance in the Jihuite dam, the introduction of discharge control programs and incentives for farmers to use agrochemicals and natural fertilizers rational [11-22].

\section{Acknowledgment}

The realization of this research was possible thanks to the collaboration of the Guadalajara University, with the technical support of the UDG-561 Academic Group and the Lab for Water Analysis from the CUAltos.

\section{References}

1. Castañeda A (2018) Administración de los recursos hídricos en el occidente de México:Evolución de la gestión del agua en una microcuenca de Los Altos de Jalisco.

2. Rivera R, Palacios-Vélez OL, Morales JC, Belmont MA, Nikolski-gavrilov I, et al. (2007) Contaminación por coliformes y helmintos en los ríos Texcoco, Chapingo y San Bernardino tributarios de la parte oriental de la cuenca del Valle de México. Rev Int Contam Ambient 23: 69-77.

3. Samboni R, Eugenia N, Escobar C, Escobar Y, Carlos J (2007) Revisión de parámetros fisicoquímicos como indicadores de calidad y contaminación del agua. Jornal of Engineering and Research 27: 172-181.

4. IIEG Jalisco (2018) Tepatitlán de morelos diagnóstico del municipio. Instituto de Información Estadística y Geográfica Jalisco, Zapopan, Mexico.

5. IIEG Jalisco (2014) Underground. Instituto Nacional de Estadísticas y Geografía Jalisco, Zapopan, Mexico.

6. Conagua (2007) Normas oficiales mexicanas. 
Citation: Villanueva AAC (2020) Physical-Chemical Assessment of Surface Water Pollution in a Micro-Water Basin in the Highlands of Jalisco, Mexico. J Environ Sci Curr Res 3: 020

7. Flores (2012) Con información de SEMADES, 2000, 2010; SEMARNAT, 2000; CONAGUA, 2010; CONABIO, 2010; INEGI, 1982, 2005,2007; CONAFOR, 2007; CEA, 2007; CCA, 2010.

8. APHA-AWWA-WEF (2005) (2017) Standard methods for the examination of water and wastewater. In. Rice EW, Baird RB, Eaton AD (eds). American Public Health Association, American Water Works Association, Water Environment Federation. Washington, DC., USA.

9. Comisión Estatal del Agua del Estado de Jalisco CEA Jal (2015) Ficha Técnica Hidrológica del Municipio de Tepatitlán de Morelos. Secretaría General de Gobierno. Dirección de Publicaciones. Guadalajara, Jalisco, México.

10. Flores H (2009) Identificación de buenas prácticas agrícolas para reducir la degradación del suelo e incrementar la calidad del agua: Metodología aplicada en la cuenca hidrográfica del Jihuite. Libro Científico Núm. 1 INIFAP, Campo Experimental Centro Altos de Jalisco. Tepatitlán de Morelos Jal. México.

11. Casillas M (2013) La tercera revolución del agua. Urbanización, gestión y contaminación del agua: El caso de Tepatitlán de Morelos, Jalisco, México, durante el siglo XX. Jaen University, Jaén, Spain.

12. Castañe PM, Loez CR, Olguín HF, Puig A, Rovedatti MG, et al. (1998) Caracterización y variación espacial de parámetros fisicoquímicos y del plancton en un río urbano contaminado (río Reconquista, Argentina)". En Revista Internacional de Contaminación Ambiental 14: 1-9.

13. Castañeda J (2001) Diagnóstico de la situación que guarda la contaminación de los cuerpos de agua superficiales y subterráneos en la región del Rio Santiguo y propuesta de programa de saneamiento". En boletín de información del Consejo del Rio Santiago. México.

14. Chapman D (1996) Water quality assessment: A guide to the use of biota, sediments and water in environmental monitoring. UNESCO/WHO/ UNE,. Champan \& Hall, London, UK.
15. López HEF, Corral JAR, Orozco CM, Villaseñor PZ, Chávez AAD (2014) Aplicación del modelo EPIC para evaluar el efecto del cambio climático y prácticas de manejo sobre el rendimiento de grano en maíz de temporal. En revista Mexicana de Ciencias Agrícolas 10: 2007-2020.

16. GMT (2018) Recursos naturales: Hidrología superficial. Gobierno Municipal de Tepatitlán, Jalisco, Mexico.

17. Guzmán Colis G, Ramírez López EM, Thalasso F, Rodríguez-Narciso S, Guerrero-Barrera AL, et al. (2011) Estudio sobre los niveles de contaminación de los cuerpos de agua superficiales y subterráneos relacionados con el cauce del Rio San Pedro. Tesis doctoral, Centro de Ciencias Básicas. Universidad Autónoma de Aguascalientes. Aguascalientes México 27.

18. Marín RG (2003) Fisicoquímica y microbiología de los medios acuáticos: Tratamiento y control de calidad de agua. Ediciones Días de Santos. Madrid, Spain.

19. Mora C, Flores Garnica JG, Flores HE, Rubio Arias H, Chávez Durán AA, et al. (2018) Variaciones espacio-temporales y modelaje de la concentración de oxígeno disuelto en el lago de Chapala, Mexico. In Tecnología y Ciencias del Agua 9: 39-52.

20. Oswald U (2011) Water resources in Mexico: Scarcity, degradation, stress, conflicts, management and policy: Hexagon series on human, environmental, security and peace. Springer London-Ney York.

21. Rodríguez A, García PL, García RR, Valiño MD, Fernández SV, et al (2006) Tratamientos avanzados de aguas residuales industriales. Informe de vigilancia tecnológica. Círculo de Innovación en Tecnologías Medioambientales y Energía. Dirección General de Universidades e Investigación, Madrid, Spain.

22. Sedeño J, Lopez E (2007) Water quality in the Rio Lerma, Mexico: An overview of the last quarter of the twentieth century. In Water Resources Management, Springer, Netherlands. 


\section{di}

Advances In Industrial Biotechnology | ISSN: 2639-5665

Advances In Microbiology Research | ISSN: 2689-694X

Archives Of Surgery And Surgical Education | ISSN: 2689-3126

Archives Of Urology

Archives Of Zoological Studies | ISSN: 2640-7779

Current Trends Medical And Biological Engineering

International Journal Of Case Reports And Therapeutic Studies | ISSN: 2689-310X

Journal Of Addiction \& Addictive Disorders | ISSN: 2578-7276

Journal Of Agronomy \& Agricultural Science | ISSN: 2689-8292

Journal Of AIDS Clinical Research \& STDs | ISSN: 2572-7370

Journal Of Alcoholism Drug Abuse \& Substance Dependence | ISSN: 2572-9594

Journal Of Allergy Disorders \& Therapy | ISSN: 2470-749X

Journal Of Alternative Complementary \& Integrative Medicine | ISSN: 2470-7562

Journal Of Alzheimers \& Neurodegenerative Diseases | ISSN: 2572-9608

Journal Of Anesthesia \& Clinical Care | ISSN: 2378-8879

Journal Of Angiology \& Vascular Surgery | ISSN: 2572-7397

Journal Of Animal Research \& Veterinary Science | ISSN: 2639-3751

Journal Of Aquaculture \& Fisheries | ISSN: 2576-5523

Journal Of Atmospheric \& Earth Sciences | ISSN: 2689-8780

Journal Of Biotech Research \& Biochemistry

Journal Of Brain \& Neuroscience Research

Journal Of Cancer Biology \& Treatment | ISSN: 2470-7546

Journal Of Cardiology Study \& Research | ISSN: 2640-768X

Journal Of Cell Biology \& Cell Metabolism | ISSN: 2381-1943

Journal Of Clinical Dermatology \& Therapy | ISSN: 2378-8771

Journal Of Clinical Immunology \& Immunotherapy | ISSN: 2378-8844

Journal Of Clinical Studies \& Medical Case Reports | ISSN: 2378-8801

Journal Of Community Medicine \& Public Health Care | ISSN: 2381-1978

Journal Of Cytology \& Tissue Biology | ISSN: 2378-9107

Journal Of Dairy Research \& Technology | ISSN: 2688-9315

Journal Of Dentistry Oral Health \& Cosmesis | ISSN: 2473-6783

Journal Of Diabetes \& Metabolic Disorders | ISSN: 2381-201X

Journal Of Emergency Medicine Trauma \& Surgical Care | ISSN: 2378-8798

Journal Of Environmental Science Current Research | ISSN: 2643-5020

Journal Of Food Science \& Nutrition | ISSN: 2470-1076

Journal Of Forensic Legal \& Investigative Sciences | ISSN: 2473-733X

Journal Of Gastroenterology \& Hepatology Research | ISSN: 2574-2566
Journal Of Genetics \& Genomic Sciences | ISSN: 2574-2485

Journal Of Gerontology \& Geriatric Medicine | ISSN: 2381-8662

Journal Of Hematology Blood Transfusion \& Disorders | ISSN: 2572-2999

Journal Of Hospice \& Palliative Medical Care

Journal Of Human Endocrinology | ISSN: 2572-9640

Journal Of Infectious \& Non Infectious Diseases | ISSN: 2381-8654

Journal Of Internal Medicine \& Primary Healthcare | ISSN: 2574-2493

Journal Of Light \& Laser Current Trends

Journal Of Medicine Study \& Research | ISSN: 2639-5657

Journal Of Modern Chemical Sciences

Journal Of Nanotechnology Nanomedicine \& Nanobiotechnology | ISSN: 2381-2044 Journal Of Neonatology \& Clinical Pediatrics | ISSN: 2378-878X

Journal Of Nephrology \& Renal Therapy | ISSN: 2473-7313

Journal Of Non Invasive Vascular Investigation | ISSN: 2572-7400

Journal Of Nuclear Medicine Radiology \& Radiation Therapy | ISSN: 2572-7419

Journal Of Obesity \& Weight Loss | ISSN: 2473-7372

Journal Of Ophthalmology \& Clinical Research | ISSN: 2378-8887

Journal Of Orthopedic Research \& Physiotherapy | ISSN: 2381-2052

Journal Of Otolaryngology Head \& Neck Surgery | ISSN: 2573-010X

Journal Of Pathology Clinical \& Medical Research

Journal Of Pharmacology Pharmaceutics \& Pharmacovigilance | ISSN: 2639-5649

Journal Of Physical Medicine Rehabilitation \& Disabilities | ISSN: 2381-8670

Journal Of Plant Science Current Research | ISSN: 2639-3743

Journal Of Practical \& Professional Nursing | ISSN: 2639-5681

Journal Of Protein Research \& Bioinformatics

Journal Of Psychiatry Depression \& Anxiety | ISSN: 2573-0150

Journal Of Pulmonary Medicine \& Respiratory Research | ISSN: 2573-0177

Journal Of Reproductive Medicine Gynaecology \& Obstetrics | ISSN: 2574-2574

Journal Of Stem Cells Research Development \& Therapy | ISSN: 2381-2060

Journal Of Surgery Current Trends \& Innovations | ISSN: 2578-7284

Journal Of Toxicology Current Research | ISSN: 2639-3735

Journal Of Translational Science And Research

Journal Of Vaccines Research \& Vaccination | ISSN: 2573-0193

Journal Of Virology \& Antivirals

Sports Medicine And Injury Care Journal | ISSN: 2689-8829

Trends In Anatomy \& Physiology | ISSN: 2640-7752

Submit Your Manuscript: https://www.heraldopenaccess.us/submit-manuscript 